\title{
Characterization of the ovary fatty acids composition of Rhamdia quelen (Quoy \& Gaimard) (Teleostei: Siluriformes), throughout their reproductive cycle
}

\author{
Rodrigo Vargas Anidoํㅡ, Evoy Zaniboni-Filho', Alexandre Sachsida Garcia², Sueli \\ Regina Baggio ${ }^{3}$ and Débora Machado Fracalossi ${ }^{1}$
}

\begin{abstract}
Knowledge about gonad fatty acid composition is important for broodstock diet formulation. This study characterized ovary fatty acid composition of wild female jundiá catfish (Rhamdia quelen) in their different gonadal maturation stages. Female jundiá $(\mathrm{n}=36$, average weight $=383.8 \pm 208.8 \mathrm{~g})$ were captured in the rio Uruguay, comprising all seasons. Ovaries were extracted and classified according to their gonadal maturation stage. Gonad-somatic ratio varied significantly among seasons, being higher in spring (3.7), followed by summer (2.2), winter (0.9) and autumn (0.6). Main fatty acids groups detected were: saturated $(\mathrm{SFA}=35.5 \%)$, monounsaturated $(\mathrm{MUFA}=28.1 \%)$ and polyunsaturated fatty acids $(\mathrm{PUFA}=$ $33.5 \%$ ). Over the four seasons, palmitic acid was recorded in large quantities, followed by docosahexaenoic acid (DHA) and arachidonic acid (ARA). ARA was present in higher concentrations in immature or maturing ovaries, and its content decreased along the maturation process. Conversely, DHA and eicosapentaenoic acid (EPA) contents increased during maturation. Such variation resulted in an increase in EPA/ARA and DHA/ARA ratios in mature gonads, which can be important for successful breeding. Such findings suggest that jundiá broodstock diets should contain lipids that provide long chain polyunsaturated fatty acids from both the n-3 and n-6 series to ensure gonadal maturation completion.
\end{abstract}

O conhecimento da composição de ácidos graxos da gônada, como dos fatores que a influenciam são importantes na formulação de dietas para reprodutores de qualquer espécie. O presente estudo caracteriza a composição de ácidos graxos da gônada de fêmeas de jundiá (Rhamdia quelen) selvagens em seus diferentes estágios de maturação gonadal. Fêmeas de jundiá $(\mathrm{n}=36)$ com peso médio de $383,8 \pm 208,8 \mathrm{~g}$ foram capturadas no alto rio Uruguai, ao longo de um ano, abrangendo as quatro estações. As gônadas foram extraídas, classificadas e posteriormente sua composição de ácidos graxos foi determinada. A relação gônado-somática variou significativamente entre as estações, sendo maior na primavera $(3,7)$, seguida de verão $(2,2)$, inverno $(0,9)$ e no outono $(0,6)$. Os principais grupos de ácidos graxos detectados foram: saturados $(35,5 \pm 3,5 \%)$, monoinsaturados $(28,1 \pm 4,3 \%)$ e ácidos graxos poli-insaturados $(33,5 \pm 3,0 \%)$, com aproximadamente $30 \%$ para cada grupo. Ao longo das quatro estações, o ácido palmítico foi registrado em grandes quantidades, seguido do ácido docosahexaenóico (DHA) e ácido araquidônico (ARA). O ácido araquidônico estava presente em concentrações mais elevadas nas gônadas imaturas que nas gônadas maturas, e seu conteúdo diminuído ao longo do processo de maturação. Inversamente, o conteúdo de DHA e ácido eicosapentaenoico (EPA) aumentaram durante o processo de maturação. Tal variação resultou num aumento das relações EPA/ARA e DHA/ARA nas gônadas maturas, fato que pode ser importante para o sucesso da reprodução no jundiá. Tais resultados sugerem que dietas para reprodutores da espécie devem conter fontes de lipídios que proporcionem ácidos graxos de cadeia longa de ambas series (n-3 e n-6) para assegurar uma correta maturação final da gônada.

Keywords: Arachidonic acid, Broodstock diet, Docosahexaenoic acid, Eicosapentaenoic acid, Gonadal maturation.

\footnotetext{
'Departamento de Aquacultura, Centro de Ciências Agrárias, Universidade Federal de Santa Catarina, Rodovia Admar Gonzaga, 1346, 88034-001 Florianópolis, SC, Brazil. (RVA) roduruguaio@gmail.com (corresponding author), (EZF) zaniboni@cca.ufsc.br, (DMF) deboraf@cca.ufsc.br

${ }^{2}$ Centro de Estudos do Mar, Universidade Federal do Paraná, Caixa Postal 50.002, 88255-000 Pontal do Paraná, PR, Brazil. alesachsida@ufpr.br

${ }^{3}$ Centro de Química de Alimentos e Nutrição Aplicada, Instituto de Tecnologia de Alimentos, Avenida Brasil, 2880, 13070-178 Campinas, SP, Brazil.sueli@ital.sp.gov.br
} 


\section{Introduction}

Fatty acid composition in fish is influenced by extrinsic factors, such as diet and water temperature, as well as intrinsic ones, such as body tissue and development stage, among others (Miller et al., 2006; Turchini \& Francis, 2009; Henrotte et al., 2011; Trushenski et al., 2011). Gonads are more resistant to changes in fatty acid composition when compared to other tissues, since its composition is genetically determined to allow adequate embryo development (Sargent et al., 2002). Growth essays on fatty acid requirements for broodstock are costly and time consuming. Therefore, knowledge about gonad fatty acid composition of wild specimens is an important tool to assist in broodstock diet formulation. Additionally, fatty acids are metabolized differently during the reproductive cycle: while some are catabolized for energy, others are stored in the gonad for structural purposes, such as membrane formation or eicosanoid synthesis (Mazorra et al., 2003; Jerez et al., 2016). For example, arachidonic acid (ARA, 20:4 n-6) is one of the major nutrients to ensure reproductive success in many fish species (Tocher, 2010), as is the main precursor for the 2-series prostaglandins (PG-2), eicosanoids that stimulate steroid synthesis in the ovary, trigger oocyte maturation and affect the sexual behavior of females (Mercure \& Van der Kraak, 1995; Tocher, 2003).

Jundiá catfish, Rhamdia quelen (Quoy \& Gaimard, 1824), is a freshwater fish of the Heptapteridae family that is geographically widely distributed (Bichuette \& Trajano, 2003) and has growing commercial interest in Southern Brazil, Argentina and Uruguay (Baldisserotto \& Radunz Neto, 2004). Jundiá reproductive strategy consists of early partial spawnings along a reproductive cycle that extends from October to March in the Southern region of Brazil. The increase in temperature it is suggested as the key factor in their gonadal maturation (Barcellos et al., 2001; Ghiraldelli et al., 2007; Reidel et al., 2010) and partial spawning is an adaptive strategy to fluctuations in food supply, resulting in species preservation in unfavorable abiotic conditions (Nakatani et al., 1997). Jundiá starts spawning early in life; gonad maturation occurs as early as seven months for males and twelve months for females (Ghiraldelli et al., 2007). The jundiá mature oocyte, like in many species, is characterized by the presence of vitelline reserves, necessary to successfully overcome the endogenous feeding larvae stage (Coward et al., 2002). Such reserves are largely supplied by diet, particularly essential fatty acids [18:2 n-6 (linoleic acid), 18:3 n-3 (linolenic acid), n-3 and n-6 LC-PUFA (DHA, EPA and ARA)], which are not synthesized by most fish (Tocher, 2003). It is generally believed that freshwater fish are capable of converting 18:2 n-6 and 18:3 n-3 to their long chain polyunsaturated fatty acids (LC-PUFA, fatty acids with $\geq 20$ carbons). In contrast, marine fish are not capable of these conversions and it is believed that this difference stems primarily from a deficiency impairment of the $\Delta 5$ fatty acid desaturase.
These limitations have important implications for both essential fatty acid synthesis in aquatic animals and their prospective dietary requirements.

Additionally, considering the average size of mature female gonads in relation to body weight, jundiá presents gonads larger than $83 \%$ of the 62 fish species analyzed from the rio Paraná (Vazzoler, 1996). Thus, it is evident the high energy demanded for jundiá reproductive cycle and the importance of an adequate nutrition at this developmental stage.

Knowledge of gonad fatty acid composition and the factors that influence it are fundamental to the success of captive breeding and larval rearing (Navas et al., 1997). There are few studies on jundiá catfish gonad fatty acid composition in nature (Vargas \& Bessonart, 2007; Lemos, 2008), but none of these studies report the composition throughout the reproductive cycle. Such information is important when establishing the dietary fatty acid requirements of broodstock jundiá for appropriate diet formulation (Reidel et al., 2010). Here, was characterized the gonad fatty acid composition of wild jundiá females in their different stages of maturation throughout the reproductive cycle.

\section{Material and Methods}

Study area. The rio Uruguay is located in the sub-tropical Southern Brazil $\left(28^{\circ} 10^{\prime} \mathrm{S}\right.$ and $\left.37^{\circ} 08^{\prime} \mathrm{S}\right)$ with a basin of approximately $365,000 \mathrm{~km}^{2}$, where four well-defined seasons occur: summer, fall, winter and spring. This study was carried out in the upper stretch of the river, known as upper Uruguay, where river bed is well wedged between steep slopes. Fish were collected in four sampling points within a $200 \mathrm{~km}$ radius, located upstream of Barra Grande dam, a major hydroelectric plant in the region (Fig. 1). Fish were considered as originating from a single point, considering that none of the analyzed variables differed among the four geographical sampling points.

Gonad sampling and water quality determination. Four samples were collected in the years 2007 and 2008, one in each season: spring (October 2007), summer (January 2008), fall (April 2008), and winter (July 2008). Thirty-six female jundiá $(\mathrm{n}=36$, nine fish per station) - average weight $=383.8+208.8 \mathrm{~g}-$ were sampled. Fish were collected with gillnets and bottom long lines, placed at dusk and collected at dawn of the following day. Voucher specimens were sent to the Museu de Zoologia da Universidade Estadual de Londrina (MZUEL 10224, 10225, 10226, 10227, 10228). Water quality variables such as temperature, dissolved oxygen, $\mathrm{pH}$, transparency, and conductivity were measured at the time of placement and collection of the fishing gear. Immediately after capture, fish were measured, weighed and sexed. Gonad weight of each specimen was recorded to estimate gonad-somatic ratio (GSR) according to the following equation: 


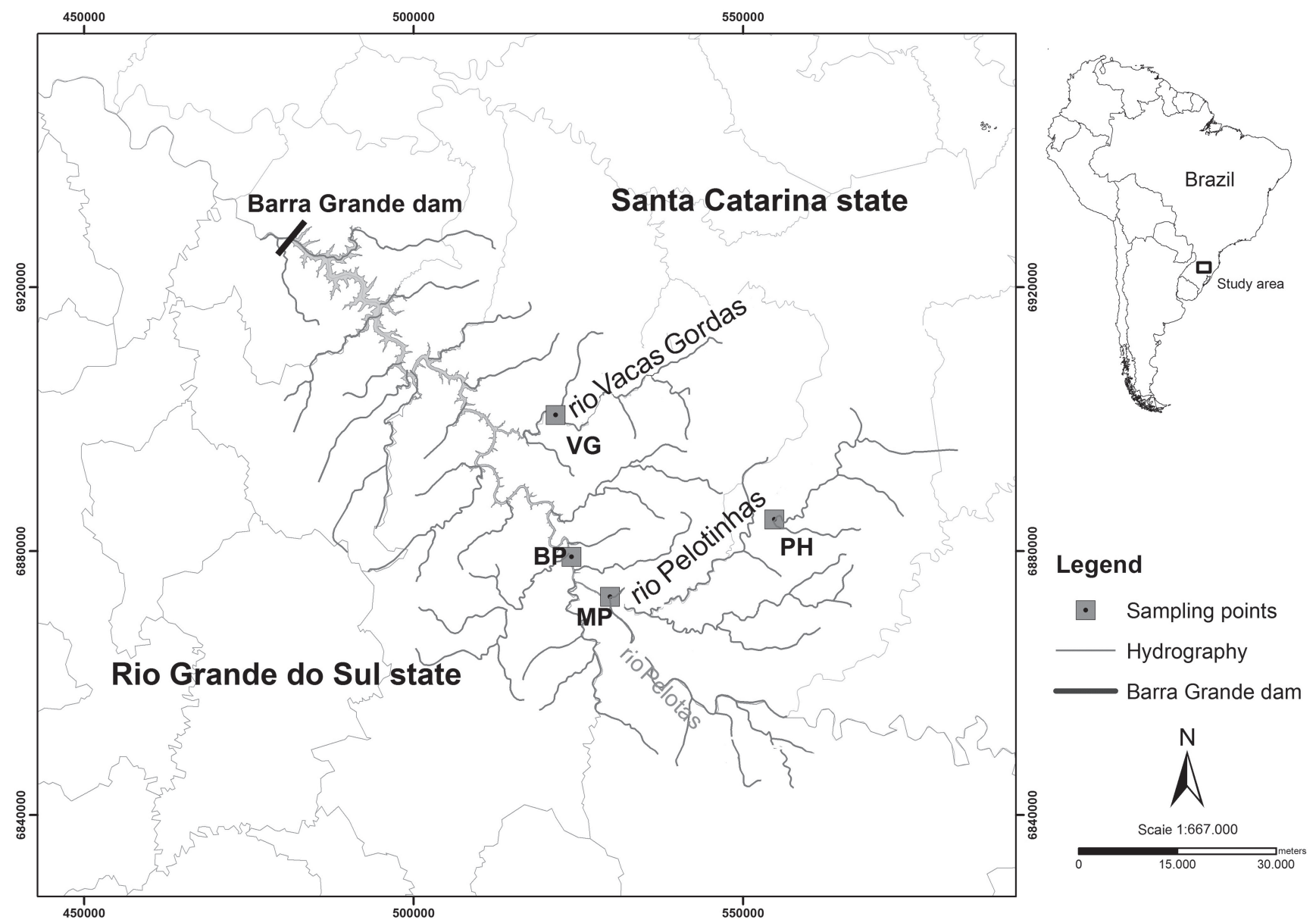

Fig. 1. Adult Rhamdia quelen sampling points location in the upper rio Uruguay. Geographical location of the points: rio

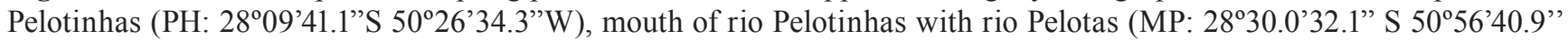

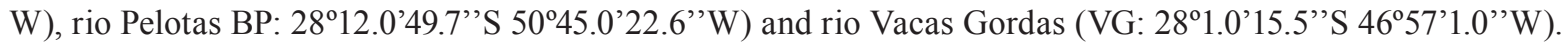

Gonadosomatic ratio $(\mathrm{GSR})=100 *($ gonad weight/total body weight)

Once collected, gonads were immediately frozen in liquid nitrogen $\left(-196^{\circ} \mathrm{C}\right)$ for transport to the laboratory where they were stored $\left(-80^{\circ} \mathrm{C}\right)$ until fatty acid analysis. Gonadal maturation stage (GMS) of each female was determined according to Ghiraldelli et al. (2007), which featured four maturation stages with such respective values: GMS I = Immature (GMS $\leq 0.4)$, GMS II = Initial maturation GMS $>0.4$ to $\leq 0.8)$, GMS III $=$ Final maturation $($ GMS $0.8<$ to $\leq 2)$, and GMS IV = Mature (GMS $>2$ ). The frequency of occurrence of each maturation stage $\left(\mathrm{F}_{\mathrm{GMS} x}\right)$, within each season, was estimated using the following equation:

$\operatorname{GMS}_{\mathrm{x}}(\%)=100 *$ (total number of females with $\mathrm{GMS}_{\mathrm{x}}$ per season / total number of females per season)

Lipid extraction and fatty acid composition. Gonad lipids were extracted in chloroform/methanol (Bligh \& Dyer, 1959), and the fatty acid methyl esters prepared by transesterification, using sulfuric acid in methanol, according to Christie (1982). Fatty acid determination was performed on a VARIAN gas chromatograph, model 3900, equipped with a Chrompack CP-SIL 88 capillary column, a flame-ionization detector and STAR 800 software. The initial column temperature was $120^{\circ} \mathrm{C}$ for $5 \mathrm{~min}$. Column temperature increased from 120 to $220^{\circ} \mathrm{C}$ at $3^{\circ} \mathrm{C} \mathrm{min}^{-1}$, from 220 to $235^{\circ} \mathrm{C}$ at $1^{\circ} \mathrm{C} \mathrm{min}-1$, and maintained at $235^{\circ} \mathrm{C}$ for 12 min. Hydrogen was the carrier gas at a flow rate of $1 \mathrm{~mL}$ $\min ^{-1}$. Fatty acids were identified by comparison to a known standard (37 Supelco FAME Mix 47885-U, Bellefonte, PA, USA) and were quantified by area normalization. Results were expressed in percentage of total identified fatty acids.

Statistical analyses. Data were checked for normality (Kolmogorov-Smirnoff test), variance homogeneity (Levene test), and independence of residues prior to ANOVA test. Average gonad fatty-acid composition among maturation stages was compared by Tukey test, when appropriated. A significance level of $5 \%$ was adopted. Gonads were considered as originating from a single point, considering that none of the analyzed variables differed among the four geographical sampling points. 


\section{Results}

Water quality not varied significantly among seasons (Table 1), except water temperature. As expected, water temperature clearly characterized the four seasons, with lower values during the winter and higher during the summer; whereas fall and spring showed intermediate temperatures $(p<0.05)$. The other water quality variables were not significantly different among seasons and averaged: $8.3 \pm 1.7 \mathrm{mg} \mathrm{L}^{-1}$ dissolved oxygen, $6.8 \pm$ $0.5 \mathrm{pH}, 136.8 \pm 44.2 \mathrm{~cm}$ transparency, and $27.5 \pm 7.7$ $\mu \mathrm{s} \mathrm{cm} \mathrm{cm}^{-1}$ conductivity. Captured females showed a large variation in weight and length among and within each sampling station. Females captured in spring and fall were significantly higher than those sampled in remaining seasons (Table 1).

Table 1. Water quality variables of upper rio Uruguay, morphometric records and frequency of female Rhamdia quelen maturation stages of captured in each season. ${ }^{1}$ The figures for each station are averages of the four sampling points. ${ }^{2}$ Averages for each season were calculated with nine females. Weight magnitude in $\mathrm{g}$ for each season was: summer $=53$ to 1184 , autumn $=342$ to 754 , winter $=73$ to 447 , spring $=355$ to 987 . Length range in $\mathrm{cm}$ for each station was: summer $=217$ to 460 , autumn $=335$ to 495 , winter $=207$ to 350 , spring $=332$ to $454 .{ }^{3} \mathrm{GMS}=$ gonadal maturation stage. According to Girhaldelli (2007): GMS I = Immature (gonad-somatic relationship $(\mathrm{GSR}) \leq 0.4)$; GMS II = Initial maturation $(0.4<$ GSR $\leq 0.8)$, GMS III = final maturation $(0.8<$ GSR $\leq 2)$ and GMS IV = Mature $(\mathrm{GSR}>2) .{ }^{3}$ The values are average \pm DST.

\begin{tabular}{|c|c|c|c|c|}
\hline & Summer & Fall & Winter & Spring \\
\hline \multicolumn{5}{|c|}{ Water quality ${ }^{1}$} \\
\hline Temperature, ${ }^{\circ} \mathrm{C}$ & $22.2 \pm 1.0^{\mathrm{a}}$ & $17.3 \pm 1.3^{c}$ & $12.9 \pm 1.1^{\mathrm{d}}$ & $19.6 \pm 1.2^{\mathrm{b}}$ \\
\hline Dissolved oxygen, $\mathrm{mg} \mathrm{L}^{-1}$ & $8.1 \pm 1.2$ & $8.0 \pm 0.3$ & $9.0 \pm 0.5$ & $5.3 \pm 0.3$ \\
\hline $\mathrm{pH}$ & $7.3 \pm 0.7$ & $6.6 \pm 0.2$ & $7.0 \pm 0.2$ & $6.3 \pm 0.2$ \\
\hline Transparency, cm & $167 \pm 35.1$ & $73 \pm 23.1$ & $148 \pm 23.6$ & $160 \pm 26.5$ \\
\hline Conductivity, $\mu \mathrm{s} \mathrm{cm}^{-1}$ & $37.7 \pm 3.7$ & $28.7 \pm 6.1$ & $19.3 \pm 1.3$ & $24.3 \pm 2.0$ \\
\hline \multicolumn{5}{|c|}{ Morphometric records ${ }^{2}$} \\
\hline Average weight, g & $265.4 \pm 350.7^{\mathrm{b}}$ & $522.7 \pm 150.4^{\mathrm{a}}$ & $155.1 \pm 120.2^{b}$ & $592.0 \pm 214.2^{\mathrm{a}}$ \\
\hline Average length, $\mathrm{cm}$ & $286.9 \pm 82.2^{\mathrm{b}}$ & $396.7 \pm 48.4^{\mathrm{a}}$ & $250.6 \pm 46.3^{\mathrm{b}}$ & $386.7 \pm 42.3^{\mathrm{a}}$ \\
\hline Gonad-somatic ratio, $\%$ & $2.2 \pm 2.6^{b}$ & $0.6 \pm 0.1^{\mathrm{c}}$ & $0.9 \pm 0.3^{\mathrm{c}}$ & $3.7 \pm 1.9^{\mathrm{a}}$ \\
\hline Lipids, \% ww & $4.2 \pm 2.5$ & $3.2 \pm 3.6$ & $3.2 \pm 2.1$ & $3.8 \pm 4.6$ \\
\hline \multicolumn{5}{|c|}{ GMS Frequency $(\%)^{3}$} \\
\hline GMS I (Immature) & 22.2 & 11.1 & - & - \\
\hline GMS II (Initial Maturation) & 11.1 & 88.9 & 33.3 & 11.1 \\
\hline GMS III (Final Maturation) & 33.3 & - & 66.7 & 22.2 \\
\hline GMS IV (Mature) & 33.3 & - & - & 66.7 \\
\hline
\end{tabular}

Female GSR varied significantly within seasons (Table 1). Female sampled in spring showed higher GSR, followed by females caught in summer, autumn $(0.6 \pm$ $0.1)$, and winter $(0.9 \pm 0.3)$. Spring was the season with the highest proportion of mature specimens (67\%), while summer season was the most heterogeneous season, with females in all gonadal maturation stages. In the fall, most of the females were in the initial maturation stage $(89 \%)$ and in the winter, only females at initial or final maturity stage were captured (Table 1).

Main fatty acids groups detected in the gonads of captured females were: saturated fatty acids $(\mathrm{SFA}=35.5 \pm$ $3.5 \%)$, monounsaturated fatty acids (MUFA $=28.1 \pm 4.3 \%$ ), and polyunsaturated fatty acids $(\mathrm{PUFA}=33.5 \pm 3.0 \%$ ). Among PUFA, long chain polyunsaturated fatty acids (n-3 LC-PUFA + n-6 LC-PUFA) represented between 20 and $30 \%$ of the total fatty acids, regardless of the gonadal maturation stage (Table 2). The most abundant fatty acids were palmitic acid (PAL, 16:0) and oleic acid (OLE, 18:1 $\mathrm{n}-9$ ), representing approximately $20 \%$ of the total fatty acid each, followed by docosahexaenoic acid (DHA, 22:6 n-3) with approximately $12 \%$, stearic acid (STA, 18:0) with approximately $11 \%$ and the arachidonic acid (ARA, 20:4 n-6) with 10\%. Linoleic acid (LOA, 18:2 n-6), linolenic acid (LNA, 18:3 n-3), and eicosapentaenoic acid (EPA, 20:5 n-3) never exceeded 5\% (Table 2).

Gonad fatty acid composition varied within each maturity stage. Saturated fatty acids showed a decrease as gonads reached maturity (Table 2 ). In contrast, n-3 LCPUFA significantly increased as the maturation process progressed, recording the highest values in GMS IV. In turn, MUFA remained constant with average values of $28 \%$ of total fatty acids, regardless of gonadal maturation stage. Gonad unsaturated: saturated fatty acid ratio (UFA/ SFA) increased significantly with sexual maturation (Fig. 2). Maturation process was marked by significant increase in EPA/DHA ratio as well as decrease in ARA. We also recorded a significant increase in the $n-3 / n-6$ and EPA/ARA ratios when gonads reached stage IV or mature (Table 2).

The $n-3 / n-6$ and UFA/SFA ratios in gonads within a maturity stage but across different seasons of the year were significantly higher in colder seasons (Fig. 3). Conversely, the EPA/ARA relation in immature gonads did not vary, regardless of the season in which the female was sampled. However, in the gonads in the maturation process (GMS II and III), the EPA/ARA ratio was higher in individuals sampled during winter and spring. In mature gonads, this ratio was higher in females collected in the spring when compared with those collected in the summer (Fig. 3). Arachidonic acid, DHA and EPA concentrations in maturing and mature gonads (II, III and IV) were not different among seasons, but immature gonads (I), from females collected in the autumn, had higher concentrations of these fatty acids when compared to those found in females sampled in summer (Fig. 3). 
Table 2. Fatty acid composition ( $\%$ total fatty acids) from hamdia quelen ovaries caught in the upper rio Uruguay, grouped according to gonadal maturation stage. According to Girhaldelli (2007): gonadal maturation stage (GMS) I = Immature (GSR Immature $\leq 0.4)$; GMS II $=$ Initial maturation $\left(0.4<\mathrm{GSR}_{\text {Initial Mat }} \leq 0.8\right)$, GMS III $=$ Final maturation $\left(0.8<\mathrm{GSR}_{\text {Final mat. }} \leq 2\right)$ and GMS IV $=$ Mature $\left(\mathrm{GSR}_{\text {Mature }}>2\right) .{ }^{2}$ Different letters within the same row represent significant differences, with a significance level of 5\%. ${ }^{3}$ SFA $=$ saturated fatty acids, MUFA = monounsaturated fatty acids, PUFA = polyunsaturated fatty acids, LC PUFA = polyunsaturated fatty acids longchain ( $\geq 20$ carbons). The values are average \pm DST.

\begin{tabular}{|c|c|c|c|c|}
\hline \multirow{2}{*}{ Fatty acid 2,3} & \multicolumn{4}{|c|}{ Gonadal maturation stage ${ }^{1}$} \\
\hline & I & II & III & IV \\
\hline $\mathrm{C} 14: 0$ & $3.7 \pm 1.2^{\mathrm{a}}$ & $1.7 \pm 1.6^{\mathrm{b}}$ & $2.4 \pm 2.7^{\mathrm{ab}}$ & $1.1 \pm 0.3^{b}$ \\
\hline $\mathrm{C} 15: 0$ & $1.7 \pm 0.7^{\mathrm{a}}$ & $1.3 \pm 0.9^{\mathrm{ab}}$ & $1.0 \pm 0.6^{\mathrm{bc}}$ & $0.5 \pm 0.1^{\mathrm{c}}$ \\
\hline $\mathrm{C} 16: 0$ & $18.6 \pm 1.4$ & $19.4 \pm 3.4$ & $18.5 \pm 1.9$ & $18.7 \pm 2.2$ \\
\hline $\mathrm{C} 17: 0$ & $1.0 \pm 0.6$ & $0.8 \pm 0.6$ & $1.0 \pm 0.9$ & $1.1 \pm 0.4$ \\
\hline $\mathrm{C} 18: 0$ & $11.8 \pm 1.3^{\mathrm{a}}$ & $12.7 \pm 2.9^{\mathrm{a}}$ & $12.3+2.7^{\mathrm{a}}$ & $9.3 \pm 1.4^{\mathrm{b}}$ \\
\hline $\mathrm{C} 22: 0$ & $0.6 \pm 0.4^{\mathrm{a}}$ & $0.2 \pm 0.4^{\mathrm{b}}$ & $0.3 \pm 0.4^{\mathrm{b}}$ & $0.1 \pm 0.1^{\mathrm{b}}$ \\
\hline$\sum$ SAT & $38.4 \pm 3.4^{\mathrm{a}}$ & $36.4 \pm 4.3^{\mathrm{a}}$ & $36.0 \pm 4.2^{\mathrm{ab}}$ & $31.0 \pm 2.0^{\mathrm{b}}$ \\
\hline $\mathrm{C} 14: 1$ & $0.2 \pm 0.2$ & $0.2 \pm 0.3$ & $0.2 \pm 0.2$ & $0.3 \pm 0.2$ \\
\hline $\mathrm{C} 15: 1$ & $0.6 \pm 0.1$ & $0.5 \pm 0.6$ & $0.9 \pm 1.0$ & $0.9 \pm 0.8$ \\
\hline $\mathrm{C} 16: 1$ & $4.0 \pm 2.8$ & $3.5 \pm 2.3$ & $4.3 \pm 3.6$ & $3.9 \pm 0.9$ \\
\hline $\mathrm{C} 17: 1$ & $0.9 \pm 0.5^{\mathrm{a}}$ & $0.5 \pm 0.6^{\mathrm{ab}}$ & $0.7 \pm 0.7^{\mathrm{ab}}$ & $0.3 \pm 0.2^{\mathrm{b}}$ \\
\hline C18:1 n-9 & $22.0 \pm 2.9^{\mathrm{a}}$ & $19.8 \pm 4.0^{\mathrm{ab}}$ & $18.0 \pm 2.9^{b}$ & $21.1 \pm 1.4^{\mathrm{a}}$ \\
\hline $\mathrm{C} 20: 1$ & $0.1 \pm 0.2^{\mathrm{b}}$ & $0.2 \pm 0.3^{\mathrm{b}}$ & $0.2 \pm 0.3^{b}$ & $0.7 \pm 0.4^{\mathrm{a}}$ \\
\hline $\mathrm{C} 24: 1$ & $1.7 \pm 1.6$ & $1.9 \pm 1.9$ & $2.2 \pm 2.0$ & $2.8 \pm 1.4$ \\
\hline$\sum$ MUFA & $29.4+4.9$ & $26.6+5.4$ & $26.4+5.5$ & $30.1+1.6$ \\
\hline C18:3 n-3 & $1.7 \pm 0.7^{\mathrm{a}}$ & $0.7 \pm 0.8^{\mathrm{b}}$ & $1.1 \pm 1.1^{\mathrm{ab}}$ & $1.2 \pm 0.7^{\mathrm{ab}}$ \\
\hline$C 20: 3 n-3$ & $0.2 \pm 0.2^{\mathrm{b}}$ & $0.1 \pm 0.2^{\mathrm{b}}$ & $0.4 \pm 0.5^{\mathrm{ab}}$ & $0.6 \pm 0.3^{\mathrm{a}}$ \\
\hline$C 20: 5 n-3$ & $0.7 \pm 0.5^{\mathrm{c}}$ & $1.4 \pm 1.0^{\mathrm{bc}}$ & $1.7 \pm 1.0^{\mathrm{ab}}$ & $2.3 \pm 0.3^{\mathrm{a}}$ \\
\hline$C 22: 5 n-3$ & $1.1 \pm 0.7^{b}$ & $2.2 \pm 1.3^{\mathrm{ab}}$ & $2.1 \pm 1.5^{\mathrm{ab}}$ & $2.5 \pm 1.1^{\mathrm{a}}$ \\
\hline $\mathrm{C} 22: 6 \mathrm{n}-3$ & $8.9 \pm 4.1^{\mathrm{c}}$ & $12.5 \pm 3.1^{\mathrm{ab}}$ & $11.2 \pm 3.2^{\mathrm{bc}}$ & $14.6 \pm 1.8^{\mathrm{a}}$ \\
\hline$\sum \mathrm{n}-3$ PUFA & $12.7 \pm 4.1^{\mathrm{c}}$ & $17.0 \pm 3.3^{\mathrm{b}}$ & $16.7+4.1^{\mathrm{b}}$ & $21.1+2.1^{\mathrm{a}}$ \\
\hline$\sum \mathrm{n}-3$ LC-PUFA & $11.0 \pm 4.7^{\mathrm{c}}$ & $16.3 \pm 3.6^{\mathrm{b}}$ & $15.4 \pm 3.9^{\mathrm{b}}$ & $19.9 \pm 1.8^{\mathrm{a}}$ \\
\hline C18:2 n-6 & $4.8 \pm 0.5^{\mathrm{a}}$ & $3.5 \pm 1.1^{\mathrm{ab}}$ & $4.5 \pm 2.1^{\mathrm{ab}}$ & $3.3 \pm 0.7^{\mathrm{b}}$ \\
\hline$C 20: 2 n-6$ & $1.1 \pm 0.6^{\mathrm{a}}$ & $0.3 \pm 0.4^{\mathrm{b}}$ & $0.7 \pm 1.0^{\mathrm{ab}}$ & $0.8 \pm 0.2^{\mathrm{ab}}$ \\
\hline$C 20: 3 n-6$ & $1.0 \pm 0.7^{\mathrm{b}}$ & $0.9 \pm 0.8^{b}$ & $1.2 \pm 0.8^{\mathrm{ab}}$ & $1.6 \pm 0.2^{\mathrm{a}}$ \\
\hline$C 20: 4$ n-6 & $10.5 \pm 3.6^{\mathrm{a}}$ & $12.5 \pm 2.4^{\mathrm{a}}$ & $11.7 \pm 3.8^{\mathrm{a}}$ & $7.3 \pm 1.3^{\mathrm{b}}$ \\
\hline$\sum \mathrm{n}-6$ PUFA & $17.3 \pm 3.7^{\mathrm{a}}$ & $17.3 \pm 2.2^{\mathrm{a}}$ & $18.3 \pm 3.6^{\mathrm{a}}$ & $13.5 \pm 1.2^{\mathrm{b}}$ \\
\hline$\sum \mathrm{n}-6$ LC-PUFA & $12.5 \pm 3.9$ & $13.7 \pm 2.9$ & $13.6 \pm 2.9$ & $9.8 \pm 1.6$ \\
\hline Unidentified & $2.3 \pm 2.2$ & $2.6 \pm 2.4$ & $2.7 \pm 2.8$ & $4.3 \pm 0.9$ \\
\hline$n-3 / n-6$ & $0.7 \pm 0.2^{\mathrm{b}}$ & $1.0 \pm 0.2^{\mathrm{b}}$ & $1.0 \pm 0.3^{\mathrm{b}}$ & $1.6 \pm 0.3^{\mathrm{a}}$ \\
\hline EPA/ARA & $0.1 \pm 0.1^{\mathrm{b}}$ & $0.1 \pm 0.1^{\mathrm{b}}$ & $0.2 \pm 0.1^{\mathrm{b}}$ & $0.3 \pm 0.1^{\mathrm{a}}$ \\
\hline DHA/ARA & $0.8 \pm 0.2^{\mathrm{b}}$ & $1.0 \pm 0.2^{\mathrm{b}}$ & $1.0 \pm 0.4^{\mathrm{b}}$ & $2.0 \pm 0.4^{\mathrm{a}}$ \\
\hline
\end{tabular}

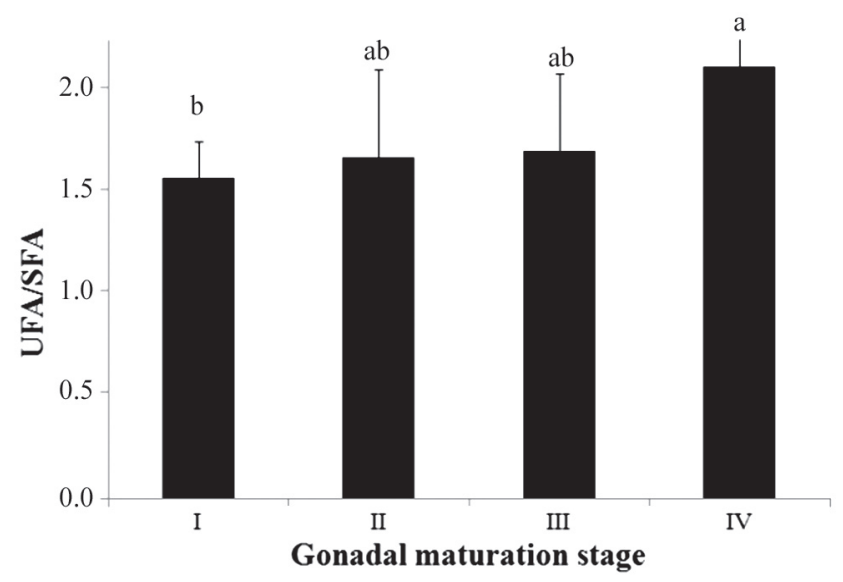

Fig. 2. Relationship between unsaturated and saturated ${ }^{1}$ fatty acids in Rhamdia quelen ovaries collected from natural environment and grouped according to their gonadal maturation stage. UFA/SFA $=$ (monounsaturated fatty acids + polyunsaturated fatty acids)/ saturated fatty acids.
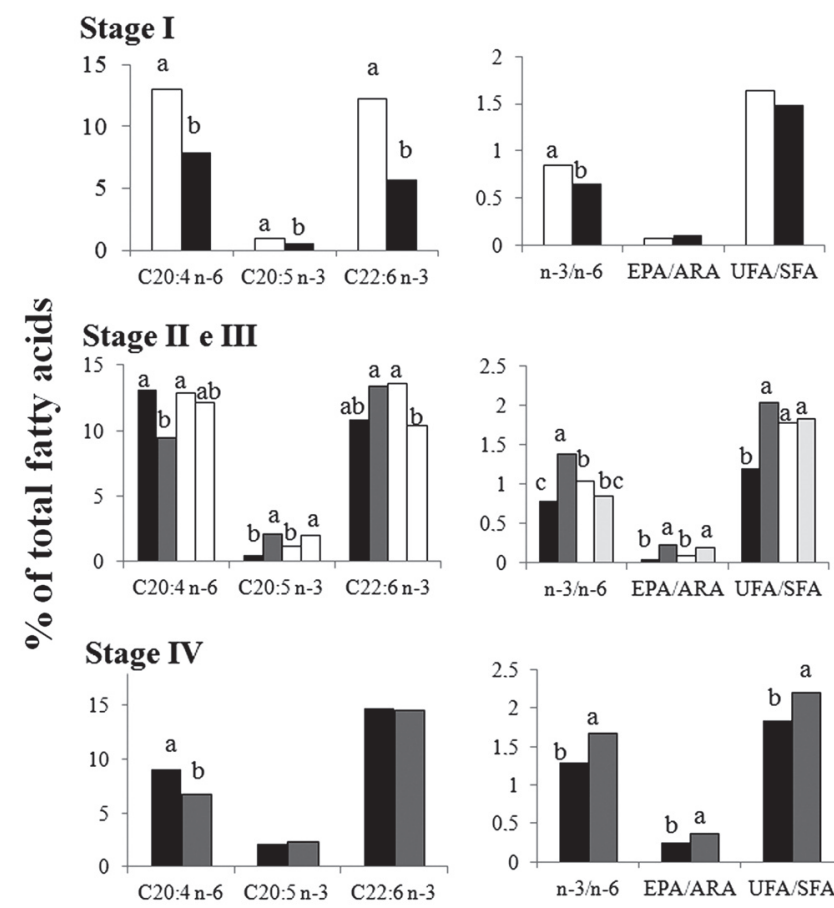

Fig. 3. Composition of fatty acids 20:4 n-6 (ARA), 20:5 n-3 (EPA) and 22:6 n-3 (DHA) and n-3/n-6, EPA/ARA relations and unsaturated fatty acids (UFA)/ saturated fatty acids (SFA) observed in Rhamdia quelen ovaries captured in different seasons: spring (dark gray), summer (black), winter (light gray) and autumn (white), and grouped according to their gonadal maturation stage (GMS) Immature $=$ I, GMS II and III = GMS in maturation and GMS IV = Mature. ${ }^{1}$ Different letter for the same fatty acid or fatty acids relation indicate significant differences at a significance level of $5 \% .{ }^{2}$ In winter females in stages of gonadal maturation I and IV, in spring females in stage of gonadal maturation I and in fall females in stage of gonadal maturation IV were not collected. 


\section{Discussion}

Frequency of maturation stages in each season and gonad-somatic ratio in female jundiá captured in the upper rio Uruguay indicate that temperature rise is one of the stimuli necessary for species maturation and spawning. This corroborates observations made for jundiá in both the natural environment (Cassini, 1998) and in confinement (Ghiraldelli et al., 2007). Several authors have reported the existence of mature jundiá catfish females during most of the year, identifying three maturation peaks associated with warmer seasons (Barcellos et al., 2001; Ghiraldelli et al., 2007; Reidel et al., 2010). In the present study, mature female catfishes on final maturation phase were recorded in three of the four stations monitored. This may be an indication that female jundiá keeps oocytes ready to spawn for extended periods or that these oocytes' reabsorption process is very rapid (Ghiraldelli et al., 2007). Another possibility, less addressed so far to jundiá, is that other factors such as nutrition are also regulating final gonad maturation process.

The different groups of fatty acids detected in jundiá ovaries showed similar percentages to those found in other freshwater species (Tocher, 2010; Vargas \& Bessonart, 2007). Saturated fatty acids always represent more than $30 \%$ of total fatty acids, which shows the importance of this group as energy supply. Similarly, samples of Nile tilapia, Oreochromis niloticus (Linnaeus, 1758), fed diets containing different sources of fat (palm oil, fish oil or flaxseed oil) for 25 weeks presented a similar percentage of saturated fatty acids $(\sim 30 \%)$ in their ovary composition (Ng \& Wang, 2011). Authors suggest that the high SFA percentage in tilapia gonads is fundamental for its reproductive success. LC-PUFA also showed high percentage $(>20 \%)$ in jundiá ovaries, with common reports of high levels of fatty acids of this group in both marine and freshwater fish ovaries (Izquierdo et al., 2001). LCPUFA are important in membrane formation and proper function (Sargent et al., 2002). The n-3/n-6 ratio in jundiá ovary increased in more advanced maturation stages and the same pattern was observed for the crustacean Marsupenaeus japonicus (Spence Bate, 1888) captured in a natural environment (Tahara \& Yano, 2004). In turn, the UFA/SFA ratio in membrane phospholipids is influenced by temperature, this being a crucial factor in determining the degree of fluidity (Hazel et al., 1991; Bowden et al., 1996; Miller et al., 2006). In the present study, lipid classes were not separated, but UFA/SFA ratio in total lipids was significantly higher in the mature stage (UFA/SFA $=2.0$ ), when compared to the immature stage (UFA/SFA $=1.4$ ). Thus, ovarian maturation in jundiá catfish is likely to be accompanied by an increase in membrane fluidity of this tissue. On the other hand, the n-3/n-6 and UFA/SFA ratios in ovaries from the same GMS but from females captured at different seasons of the year showed that cold seasons promote higher values when compared to warmer seasons
(Fig. 3). This suggests that temperature influences jundiá ovary lipid composition.

Gonadal maturation in teleost fish involves the presence of DHA, EPA and ARA to produce cell membranes and eicosanoids (Tocher, 2003). Maturation therefore is not only associated with the accumulation of lipids in the gonad, but with changes in the ratio among these fatty acids (Pérez et al., 2007). Fish ovaries have the ability to generate eicosanoids from ARA (including prostaglandins $\mathrm{PGE}_{2}$ and $\mathrm{PGF}_{2 \alpha}$ ) or from EPA (prostaglandins $\mathrm{PGE}_{1} \mathrm{e}$ $\mathrm{PGE}_{3}$ ), which are essential for the metabolism of that tissue; especially in the final maturation phase (Sargent et al., 2002). Studies in vivo and in vitro with European sea bass oocyte, Dicentrarchus labrax (Linnaeus, 1758), demonstrate unequivocally that eicosanoids generated from ARA $\left(\mathrm{PGE}_{2}\right.$ e $\left.\mathrm{PGF}_{2 \alpha}\right)$ are responsible for regulating oocyte maturation, vitellogenesis and ovulation (Sorbera et al., 2001; Bell \& Sargent, 2003). In the present study, fatty acid composition of jundiá catfish ovary showed high percentages of ARA (7.3\% to $12.5 \%)$, regardless of gonadal maturation stage. However, jundiá ovaries show a fall in ARA concentration in the final maturation stage (stage IV). This suggests ARA processing in eicosanoids at the final maturation stages. A drop in the relative ARA proportion at the end of maturation was also observed in the freshwater prawn Macrobrachium rosenbergii (de Man, 1879) collected from the natural environment; authors associate this pattern to the conversion of an important part of ARA in prostaglandins at the final gonadal maturation phase (Cavalli et al., 2001). Indeed during the ovarian maturation process of the Japanese eel, Anguilla japonica (Temminck \& Schlegel, 1846) there was also a drop in the relative percentage of ARA in the mature ovary and authors suggest that high concentrations of ARA in the final gonadal maturation stages may negatively affect egg quality (Furuita et al., 2007). Along with the reduction percentage of $\mathrm{ARA}$, female jundiá presented an increase in the EPA/ARA ratio in the final maturation stage. A similar pattern was observed in female of white sea bream, Diplodus sargus (Linnaeus, 1758), captured in different seasons (Pérez et al., 2007). Eicosapentaenoic and ARA fatty acids compete for the same enzyme complex to generate different series of prostaglandins, which have similar biological activities, but different action intensity. Thus, their relative proportion in the tissue is crucial for successful reproduction. An imbalance in EPA/ARA ratio can deregulate the production of lipid mediators involved in the reproduction (Rodriguez-Barreto et al., 2012). ARA and EPA as well as the other n-3 LC-PUFA appear to be involved at different ovarian maturation stages, leading to the need to include lipid sources containing the two series of fatty acids in the diet of jundiá broodstock. The inclusion of a combination of lipid sources in A. japonica diet, which provided the two n-3 and n-6 series at the same time with an EPA/ARA ratio of 9.2, provided an increase in egg quality (Furuita et al., 2007). Sole Solea senegalensis (Kaup, 
1858) broodstock, while fed through demand feeders for 16 months, regulated ARA intake to approximately $3 \%$ of total fatty acids in the diet (Norambuena et al., 2012). Likewise, the female catfish, Ictalurus punctatus (Rafinesque, 1818), fed different lipid sources showed high ARA values (5.4 to $9.0 \%$ ) in their oocytes (Sink \& Lochmann, 2008).

Comparative studies on gonad fatty acid composition of D. sargus, captured in natural environment and kept in confinement, demonstrated that the latter tend to have lower EPA and DHA concentration, and higher ARA concentration (Cejas et al., 2003). The reduction of EPA and DHA in the ovary of confined fish is considered a problem in artificial breeding (Ling et al., 2006). In the present study, wild female jundiá showed elevated LC-PUFA levels in their ovaries. The lack of information binding fatty acid composition of the diet to the gonads, as well as these fatty acids to the reproductive performance of the species may be limiting for successful reproduction. Thus, future studies should address dietary LC-PUFA ratios to elucidate its importance in broodstock jundiá. On the other hand, in most fishes, males and females have different energy costs compared to reproduction (Chatzifotis et al., 2004). In jundiá, both dietary and growth rate differences between sexes were reported (Fracalossi et al., 2004). Together, these factors could be determining differences in the dietary requirement of fatty acids between sexes for this species, which is also a point of interest for future research.

Several studies with marine and freshwater species demonstrate that adequate ARA concentrations in the diet stimulate oocyte maturation (Mercure \& Van der Kraak, 1996, Pérez et al., 2007, Norambuena et al., 2013). We hypothesize that associated to the temperature effect on jundiá gonadal maturation; there could be a regulatory mechanism dependent on the concentration of some nutrients in gonads such as a decrease in ARA which could act as a final maturation trigger. This mechanism would have the advantage of being directly related to food availability in the environment, a fact that would contribute to determining the most appropriate time to spawn. Further studies are warranted to test that. In addition, the results suggest that jundiá broodstock diets should contain lipids that provide LC-PUFA fatty acids from both the n-3 and n- 6 series to ensure gonadal maturation completion.

\section{Acknowledgements}

This study was funded by a grant from the Conselho Nacional de Desenvolvimento Científico e Tecnológico (CNPq). The authors would like to thank Ana Paula Rodrigues Oeda and Rodrigo Nascimento for their technical assistance during fieldwork and Figure 1 plotting, respectively. Acknowledgements are also due to the Coordenação de Aperfeiçoamento de Pessoal de Nível Superior (CAPES) and to CNPq for the fellowships granted to the first and last authors, respectively.

\section{References}

Baldisserotto, B. \& J. Radunz Neto. 2004. Criação do jundiá. Santa Maria, Editora UFSM, 232p.

Barcellos, L. J. G., G. F. Wassermann, A. P. Scott, V. M. Woehl, R. M. Quevedo, I. Ittzés, M. H. Krieger \& F. Lulhier. 2001. Steroid profiles in cultured female jundia, the siluridae Rhamdia quelen (Quoy and Gaimard, Pisces Teleostei), during the first reproductive cycle. General and Comparative Endocrinology, 121: 325-332.

Bell, J. G. \& J. R. Sargent. 2003. Arachidonic acid in aquaculture feeds: current status and future opportunities. Aquaculture, 218: 491-499.

Bichuette, M. E. \& E. Trajano. 2003. Epigean and subterranean ichthyofauna from the São Domingos karst area, Upper Tocantins River basin, Central Brazil. Journal of Fish Biology, 63: $1100-1121$.

Bligh, E. G. \& W. J. Dyer. 1959. A rapid method of total lipid extraction and purification. Canadian Journal of Biochemistry and Physiology, 37: 911-917.

Bowden, L. A., C. J. Restall \& A. F. Rowley. 1996. The influence of environmental temperature on membrane fluidity, fatty acid composition and lipoxygenase product generation in head kidney leucocytes of the rainbow trout, Oncorhynchus mykiss. Comparative Biochemistry and Physiology, 115B: 375-382.

Cassini, C. A. 1998. Estrutura da população e distribuição espacial de Pimelodus maculatus Lacépede, 1803 (Siluriformes, Pimelodidae), Rhamdia quelen (Quoy \& Gaimard, 1824, Siluriformes, Pimelodidae) e Schizodon aff. nasutus Kner, 1859 (Characiformes, Anostomidae), no Alto rio Uruguai, Brasil. Unpublished Ph. D. Dissertation, Universidade Federal de Santa Catarina, Florianópolis, 75p.

Cavalli, R. O., M. Tamtin, P. Lavens \& P. Sorgeloos. 2001. Variations in lipid classes and fatty acid content in tissues of wild Macrobrachium rosenbergii (de Man) females during maturation. Aquaculture, 193: 311-324.

Cejas, J. R., E. Almansa, J. E. Villamandos, P. Badía, A. Bolaños \& A. Lorenzo. 2003 Lipid and fatty acid composition of ovaries from wild fish and ovaries and eggs from captive fish of white sea bream (Diplodus sargus). Aquaculture, 216: 299-313.

Chatzifotis, S., P. Muje, M. Pavlidis, J. Agren, M. Paalavuo \& H. Molsa. 2004. Evolution of tissue composition and serum metabolites during gonadal development in the common dentex (Dentex dentex). Aquaculture, 236: 557-573.

Christie, W. W. 1982. Lipid analysis. England, Oxford, Pergamon Press. 207p.

Coward, K., N. R. Bromage, O. Hibbitt \& J. Parrington. 2002. Gamete physiology, fertilization and egg activation in teleost fish. Reviews in Fish Biology and Fisheries, 12: 33-58.

Fracalossi, D. M., G. Meyer, F. M. Santamaria, M. Weingartner \& E. Zaniboni Filho. 2004. Desempenho do jundiá, Rhamdia quelen, e do dourado, Salminus brasiliensis, em viveiros de terra na região sul do Brasil. Acta Scientiarum. Animal Sciences, 26: 345-352.

Furuita, H., K. Hori, Suzuki, T. Sugita \& T. Yamamoto. 2007. Effect of n-3 and n-6 fatty acids in broodstock diet on reproduction and fatty acid composition of broodstock and eggs in the Japanese eel Anguilla japonica. Aquaculture, 267: 55-61.

Ghiraldelli, L., C. Machado, D. M. Fracalossi \& E. Zaniboni Filho. 2007. Desenvolvimento gonadal do jundiá, Rhamdia quelen (Teleostei, Siluriformes), em viveiros de terra, na região sul do Brasil. Acta Scientiarum, Biological Sciences, 29: 349-356. 
Hazel, J. R., E. E. Williams, R. Livermore \& N. Mozingo. 1991. Thermal adaptation in biological membranes: functional significance of changes in phospholipid molecular species composition. Lipids, 26: 277-282.

Henrotte, E., D. Kpogue, S. N. M. Mandiki, N. Wang, J. Douxfils, J. Dick, D. Tocher \& P. Kestemont. 2011. n-3 and n-6 fatty acid bioconversion abilities in Eurasian perch (Perca fluviatilis) at two developmental stages. Aqualculture Nutrition, 17: c216c225.

Izquierdo, M. S., H. Fernández-Palacios \& A. G. J. Tacon. 2001. Effect of broodstock nutrition on reproductive performance of fish. Aquaculture, 197: 25-42.

Jerez, S., C. Rodríguez, J. R. Cejas, A. Bolaños \& A. Lorenzo. 2006. Lipid dynamics and plasma level changes of $17 \beta$-estradiol and testosterone during the spawning season of gilthead seabream (Sparus aurata) females of different ages. Comparative Biochemistry and Physiology Part B, 143: 180-189.

Lemos, L. F. 2008. Comparação do perfil de ácidos graxos de jundiá, Rhamdia quelen, cultivado e selvagem. Unpublished $\mathrm{Ph}$. D. Dissertation, Universidade Federal de Santa Catarina, Florianópolis, 48p.

Ling, S., M. K. Kuah, T. Sifzizul, T. Muhammad, S. Kolkovski \& A. C. Shu-Chien. 2006. Effect of dietary HUFA on reproductive performance, tissue fatty acid profile and desaturase and elongase mRNAs in female swordtail Xiphophorus helleri. Aquaculture, 261: 204-214.

Mazorra, C., M. Bruce, J. G. Bell, A. Davie, E. Alorend, N. Jordan, J. Rees, N. Papanikos, M. Porter \& N. Bromage. 2003. Dietary lipid enhancement of broodstock reproductive performance and egg and larval quality in Atlantic halibut (Hippoglossus hippoglossus). Aquaculture, 227: 21-33.

Mercure, F. \& G. Van Der Kraak. 1995. Inhibition of gonadotropinstimulated ovarian steroid production by polyunsaturated fatty acids in teleost fish. Lipids, 30: 547-554.

Mercure, F. \& G. Van Der Kraak. 1996. Mechanisms of action of free arachidonic acid on ovarian steroid production in the goldfish. General and Comparative Endocrinology, 102: 130-140.

Miller, M. R., P. D. Nichols, J. Barnes, N. W. Davies, E. J. Peacock \& C. G. Carter. 2006. Regiospecificity profiles of storage and membrane lipids from the gill and muscle tissue of Atlantic salmon (Salmo salar L.) grown at elevated temperature. Lipids, 41: 865-875.

Nakatani, K., G. Baumgartner \& M. Cavicchiolli. 1997. Ecologia de ovos e larvas de peixes. Pp. 281-306. In: Vazzoler, A. E. A. de M., A. A. Agostinho \& N. S. Han (Eds.). A planície de inundação do alto rio Paraná: aspectos físicos, biológicos e socioeconômicos. Maringá, Eduem.

Navas, J. M., M. Bruce, M. Thrush, B. M. Farndale, N. Bromage, S. Zanuy, M. Carrillo, J. G. Bell \& J. Ramos. 1997. The impact of seasonal alteration in the lipid composition of broodstock diets on egg quality in the European sea bass. Journal of Fish Biology, 51: 760-773.

$\mathrm{Ng}$, W. K. \& Y. Wang. 2011. Inclusion of crude palm oil in the broodstock diets of female Nile tilapia, Oreochromis niloticus, resulted in enhanced reproductive performance compared to broodfish fed diets with added fish oil or linseed oil. Aquaculture, 314: 122-131.

Norambuena, F., A. Estévez, F. J. Sánchez-Vázquez, I. Carazo \& N. Duncan. 2012. Self-selection of diets with different contents of arachidonic acid by Senegalese sole (Solea senegalensis) broodstock. Aquaculture, 364-365: 198-205.
Norambuena, F., S. Morais, A. Estévez, J. G. Bell, D. R. Tocher, J. C. Navarro, J. Cerdà \& N. Duncan. 2013. Dietary modulation of arachidonic acid metabolism in senegalese sole (Solea Senegalensis) broodstock reared in captivity. Aquaculture, 372-375: 80-88.

Pérez, M. J., C. Rodríguez, J. R. Cejas, M. V. Martín, S. Jerez \& A. Lorenzo. 2007. Lipid and fatty acid content in wild white seabream (Diplodus sargus) broodstock at different stages of the reproductive cycle. Comparative Biochemistry and Physiology Part B, 146: 187-196.

Reidel, A., W. R. Boscolo, A. Feiden \& E. Romagosa, 2010. The effect of diets with different levels of protein and energy on the process of final maturation of the gametes of Rhamdia quelen stocked in cages. Aquaculture, 298: 354-359.

Rodriguez-Barreto, D., S. Jerez, J. R. Cejas, M. V. Martin, N. G. Acosta, A. Bolaños \& A. Lorenzo. 2012. Comparative study of lipid and fatty acid composition in different tissues of wild and cultured female broodstock of greater amberjack (Seriola dumerili). Aquaculture, 360-361: 1-9.

Sargent, J. R., D. R. Tocher \& J. G. Bell. 2002. The lipids. Pp: 181257. In: Halver, J. E. \& R. W. Hardy (Eds.). Fish nutrition. $3^{\text {rd }}$ San Diego, Academic Press.

Sink, T. D. \& R. T. Lochmann. 2008. Effects of dietary lipid source and concentration on channel catfish (Ictalurus punctatus) egg biochemical composition, egg and fry production, and egg and fry quality. Aquaculture, 283: 68-76.

Sorbera, L. A., J. F. Asturiano, M. Carrillo \& S. Zanuy. 2001. Effects of polyunsaturated fatty acids and prostaglandins on oocyte maturation in a marine teleost, the European sea bass (Dicentrarchus labrax). Biology of Reproduction, 64: 382-389.

Tahara, D. \& I. Yano. 2004. Maturation-related variations in prostaglandin and fatty acid content of ovary in the kuruma prawn (Marsupenaeus japonicus). Comparative Biochemistry and Physiology Part A, 137: 631-637.

Tocher, D. R. 2003. Metabolism and functions of lipids and fatty acids in teleost fish. Reviews in Fisheries Science, 11: 107-184.

Tocher, D. R. 2010. Fatty acid requirements in ontogeny of marine and freshwater fish. Aquaculture Research, 41: 717-732.

Trushenski, J., M. Schwarz, H. Lewis, J. Laporte, B. Delbos, R. Takeuchi \& L. A. Sampaio. 2011. Effect of replacing dietary fish oil with soybean oil on production performance and fillet lipid and fatty acid composition of juvenile cobia Rachycentron canadum. Aquaculture Nutrition, 17: c437-c447.

Turchini, G. M. \& D. S. Francis. 2009. Fatty acid metabolism (desaturation, elongation and B-oxidation) in rainbow trout fed fish oil- or linseed oil-based diets. British Journal of Nutrition, 102: 69-81

Vargas, R. J. \& M. Bessonart. 2007. Composição lipídica das gônadas de duas populações de jundiá, Rhamdia quelen, em diferentes estações do ano. Boletim do Instituto de Pesca, 33 : 105-111.

Vazzoler, A. E. A. de M. 1996. Biologia da reprodução de peixes teleósteos: teoria e pratica. Maringá, Eduem; São Paulo, SBI. 169 p. 